\title{
Synthesis and preliminary pharmacological evaluation of a new putative radioiodinated AMPA receptor ligand for molecular imaging
}

\author{
By T. L. Ross",*, W. Sihver"\#, J. Ermert and H. H. Coenen \\ Institute of Neuroscience and Medicine, INM-5: Nuclear Chemistry, Forschungszentrum Jülich GmbH, 52425 Jülich, Germany
}

(Received August 13, 2012; accepted in revised form January 24, 2013)

(Published online July 15, 2013)

\section{Radioiodine / Destannylation / AMPA / Glutamate / \\ Isoquinoline / Neuroimaging}

Summary. A new (radio)iodinated AMPA receptor ligand has been developed and pharmacologically evaluated in vitro and ex vivo using rodents. The new radioligand was directly labeled by electrophilic radioiodo-destannylation with iodine131 in high radiochemical yields of $97 \%$ within 2 min. The new radioligand showed an excellent initial brain uptake of $2.1 \% \mathrm{ID} / \mathrm{g}$ at $10 \mathrm{~min}$ post injection, but a fast wash-out reduced the uptake by about 10 -fold at $60 \mathrm{~min}$ post injection. Due to high nonspecific binding accompanied with a uniform distribution in brain tissue, however, the new radiotracer appears not suitable for AMPA receptor imaging in vivo.

\section{Introduction}

The ionotropic glutamate receptor system subdivides into three different classes which are named according to their original agonists: NDMA (N-methyl-D-aspartate), AMPA ( $\alpha$-amino-3-hydroxy-5-methyl-4-isoxazolepropionic acid) and kainate (kainic acid, 2-carboxy-3-carboxymethyl-4isopropenyl-pyrrolidine). The subclass of AMPA receptors (AMPAR) is involved in learning, memory, cognition, neuronal development and synaptic plasticity. Additionally, AMPAR also mediate neuronal degeneration and cell death [1]. In neurological diseases and disorders such as epilepsy, schizophrenia, ischemia, multiple sclerosis and Parkinson's disease, AMPAR are postulated to play an important role [2]. Non-invasive molecular imaging methods such as positron emission tomography (PET) and single photon emission computed tomography (SPECT) are particularly suitable for the visualization of molecular pathophysiological processes in neurodegenerative diseases in vivo [3, 4]. There are several radioisotopes of iodine which allow application for PET $\left({ }^{124} \mathrm{I},{ }^{120} \mathrm{I}\right)$ and SPECT $\left({ }^{123} \mathrm{I},{ }^{131} \mathrm{I}\right)[5]$. For developmental work the isotope ${ }^{131} \mathrm{I}$ has a convenient

\footnotetext{
*Author for correspondence (E-mail: ross@uni-mainz.de).

"Present address: Institute of Nuclear Chemistry, JohannesGutenberg-University Mainz, 55128 Mainz, Germany.

\#\# Present address: Institute of Radiopharmacy, PF 510119, Forschungszentrum Dresden-Rossendorf, 01314 Dresden, Germany.
}<smiles>[R]c1ccc(C2c3cc(OC)c(OC)cc3CCN2C(C)=O)cc1</smiles><smiles>COc1cc2c(cc1OC)C(c1ccc(Br)cc1)N(C(C)=O)CC2</smiles>

$\mathrm{R}=\mathrm{H}, \mathrm{Br}, \mathrm{Cl}, \mathrm{F}, \mathrm{NO}_{2}, \mathrm{NH}_{2}$

$\left[{ }^{131} \mathbf{I}\right] \mathbf{5}$

Fig. 1. High affinity $N$-acetyl-1-aryl-6,7-dimethoxy-1,2,3,4-tetrahydroisoquinolines as AMPA anagonists [6,7]; and the new radioiodinated derivative $N$-acetyl-1-(4'-[ $\left.{ }^{131} \mathrm{I}\right]$ iodophenyl)-aryl-6,7-dimethoxy1,2,3,4-tetrahydro-isoquinoline $\left(\left[{ }^{131} \mathrm{I}\right] 5\right)$.

half-life of $8.02 \mathrm{~d}$ and its main $\gamma$-line of $364 \mathrm{keV}(81.2 \%)$ allows excellent detection and imaging by autoradiography, $\gamma$-counting and even SPECT.

Recently, a group of novel high affinity AMPAR antagonists has been developed ( $c f$. Fig. 1) $[6,7]$. These derivatives of $N$-acetyl-1-aryl-6,7-dimethoxy-1,2,3,4-tetrahydroisoquinoline were modified in the $4^{\prime}$-position of the aryl group of which the $4^{\prime}$-chloro derivative showed the highest potency as AMPA receptor ligand.

In the present study, the ${ }^{131} \mathrm{I}$-labeled derivative $N$-acetyl-1 - (4' - [ ${ }^{131}$ I] $]$ iodophenyl) - aryl- 6, 7-dimethoxy - 1, 2, 3,4tetrahydro-isoquinoline ([$\left.{ }^{131} \mathrm{I}\right] 5$, Fig. 1) was developed as a new AMPA receptor antagonist for molecular imaging. The new non-radioactive derivative $N$-acetyl-1-(4'-iodophenyl)-aryl-6,7-dimethoxy-1,2,3,4-tetrahydro-isoquinoline (5) was developed and fully characterized. The corresponding radiotracer was tested in pharmacological in vitro and ex vivo studies using rodents.

\section{Experimental}

\subsection{General}

All chemicals and solvents were purchased from Aldrich (Germany), Fluka (Switzerland), KMF (Germany), Acros Organics (Belgium), or Merck (Germany). They were reagent grade or better and were used without further purification. The employed high performance liquid chromatog- 
raphy (HPLC) system consists of a Knauer WellChrom Mini-Star K-500 HPLC pump, a Rheodyne-Injector block 7125 and a Merck/Hitachi UV/Vis photometer L4000. For measurement of radioactivity the outlet of the UV/Vis detector is connected to a $\mathrm{NaI}(\mathrm{Tl})$ well-type scintillation detector (EG\&G ACE Mate ${ }^{\mathrm{TM}}$ ). (radio-)HPLC was performed on a Phenomenex ${ }^{\odot}$ Luna $5 \mu \mathrm{C} 18$ column $(3 \times 250 \mathrm{~mm})$. Melting points $(\mathrm{mp})$ were determined on a Mettler FP-61 or a BÜCHI Melting Point B-540 apparatus. They are uncorrected. Mass spectra (MS) were obtained on a Thermoquest Automass Multi III mass spectrometer. ${ }^{1} \mathrm{H}$ and ${ }^{13} \mathrm{C}$ nuclear magnetic resonance (NMR) spectra were recorded at 200 or 400 and $50 \mathrm{MHz}$, respectively, on a Bruker DPX Avance 200 spectrometer. For NMR measurements substances were dissolved in $\mathrm{CDCl}_{3}, d_{6}$-DMSO or $d_{6}$-DMF and the measured chemical shifts are specified in $\delta$ ppm related to the tetramethylsilane (TMS) standard using the signals of the solvents as references. CHN-elemental analyses (EA, microanalyses) were performed on a Leco CHNS-932 CHNS analyser. The samples were burned at a temperature of $1000{ }^{\circ} \mathrm{C}$ in flowing oxygen for the analysis. $\mathrm{C}$ and $\mathrm{H}$ were measured by selective IR absorption of their combustion gases $\mathrm{CO}_{2}$ and $\mathrm{H}_{2} \mathrm{O}$. The combustion gas $\mathrm{NO}_{x}$ of $\mathrm{N}$ was converted to $\mathrm{N}_{2}$ by reduction which was determined by thermal conductivity detection. For radioiodination reactions the isotope iodine-131 was purchased from Amersham Buchler (Germany) and was obtained as sodium $\left[{ }^{131} \mathrm{I}\right]$ iodide solution (sodium hydroxide solution $\mathrm{pH} 7$ to 11 ) with $\sim 1.48 \mathrm{GBq} / \mathrm{mL}$ specific volume activity.

\subsection{4-Iodobenzyl-[2-(3',4'-dimethoxyphenyl)- ethyl]imine (3)}

A mixture of 2-(3', $4^{\prime}$-dimethoxy-phenyl)ethylamine (1, homovera-trylamine) $(10 \mathrm{mmol})$ and 4-iodobenzaldehyde (2) $(12 \mathrm{mmol})$ were heated to $100^{\circ} \mathrm{C}$ for $3 \mathrm{~h}$ in anhydrous toluene $(50 \mathrm{~mL})$. Afterwards the solvent was evaporated under reduced pressure. The oily residue was treated with ether to give a solid product which was re-crystallized from methanol to afford $\mathbf{3}$ as a white solid. Yield: $2.45 \mathrm{~g}(62 \%)$. $\mathrm{Mp}: 89.3{ }^{\circ} \mathrm{C} .{ }^{1} \mathrm{H}-\mathrm{NMR}\left(\mathrm{CDCl}_{3}\right): \delta=2.90\left(\mathrm{~d}, 2 \mathrm{H}, \mathrm{CH}_{2}-\right.$ $\mathrm{CH}_{2} \mathrm{~N}$ ), 3.76 (s, 3H, C3'-OCH $H_{3}$ ), 3.80 (s, 3H, C4'-OCH $H_{3}$ ), 3.78 (d, 2H, $\left.\mathrm{CH}_{2}-\mathrm{CH}_{2} \mathrm{~N}\right), 6.73$ (s, $\left.1 \mathrm{H}, \mathrm{CH}^{\prime}\right), 6.68(\mathrm{~s}, 1 \mathrm{H}$, $\left.\mathrm{CH}^{\prime}\right), 6.71\left(\mathrm{~d}, 1 \mathrm{H}, \mathrm{CH}^{\prime}\right), 7.38(\mathrm{~d}, 2 \mathrm{H}, \mathrm{CH} 3+5), 7.70(\mathrm{~d}$, $2 \mathrm{H}, \mathrm{CH} 2+6), 8.0(\mathrm{~s}, 1 \mathrm{H}, \mathrm{N}=\mathrm{CH} 5)$.

${ }^{13} \mathrm{C}-\mathrm{NMR}\left(\mathrm{CDCl}_{3}\right): \delta=36.8\left(1 \mathrm{C}, \mathrm{CH}_{2}-\mathrm{CH}_{2} \mathrm{~N}\right), 55.7$ $\left(1 \mathrm{C}, \mathrm{C}^{\prime}-\mathrm{OCH}_{3}\right), 55.8\left(1 \mathrm{C}, \mathrm{C}^{\prime}-\mathrm{OCH}_{3}\right), 63.3\left(1 \mathrm{C}, \mathrm{CH}_{2}-\right.$ $\left.\mathrm{CH}_{2} \mathrm{~N}\right), 97.1(1 \mathrm{C}, \mathrm{C} 4), 111.1\left(1 \mathrm{C}, \mathrm{CH}^{\prime}\right), 112.4\left(1 \mathrm{C}, C \mathrm{H}^{\prime}\right)$, $120.8\left(1 \mathrm{C}, C \mathrm{H6}^{\prime}\right), 129.5(2 \mathrm{C}, C \mathrm{H} 3+5), 132.3\left(1 \mathrm{C}, C 1^{\prime}\right)$, $135.6(1 \mathrm{C}, C 1), 137.7(2 \mathrm{C}, C \mathrm{H} 2+6), 147.3\left(1 \mathrm{C}, C 3^{\prime}-\right.$ $\left.\mathrm{OCH}_{3}\right), 148.6\left(1 \mathrm{C}, \mathrm{C}^{\prime}-\mathrm{OCH}_{3}\right), 160.4(1 \mathrm{C}, C \mathrm{H} 5) . \mathrm{MS}$ : m/e $396\left[\mathrm{MH}^{+}, 100\right], 397\left[\mathrm{MH}^{+}, 19\right], 398\left[\mathrm{MH}^{+}, 2\right] . \mathrm{EA}:$ $\mathrm{C}_{17} \mathrm{H}_{18} \mathrm{INO}_{2}$ calculated: C 51.7, $\mathrm{H} 4.59, \mathrm{~N} 3.54$; found: C 52.2, H 4.63, N 3.76 .

\subsection{6,7-Dimethoxy-1-(4'-iodophenyl)-1,2,3,4-tetra- hydroisoquinoline (4)}

3 (6.2 mmol) was given into $10 \mathrm{~mL}$ trifluoroacetic acid and the mixture was refluxed for $90 \mathrm{~min}$. Then the reaction was quenched by adding water $(\sim 10 \mathrm{~mL})$ and basified $(\mathrm{pH} \sim 8-9)$ with aqueous sodium hydroxide solution
(50\%). The product 4 precipitated and was filtered off. Re-crystallization from methanol gave the purified product. Yield: $1.33 \mathrm{~g}(54 \%)$. Mp: $152.7{ }^{\circ} \mathrm{C} .{ }^{1} \mathrm{H}-\mathrm{NMR}\left(\mathrm{CDCl}_{3}\right): \delta=$ 2.67 (d, $1 \mathrm{H}, \mathrm{CH}_{2}-\mathrm{CH}_{2}-\mathrm{NH}$, pseudo eq.), 2.84 (d, $1 \mathrm{H}, \mathrm{CH}_{2}-$ $\mathrm{CH}_{2}-\mathrm{NH}$, pseudo ax.), 2.96 (d, $1 \mathrm{H}, \mathrm{CH}_{2}-\mathrm{CH}_{2}-\mathrm{NH}$, pseudo ax.), 3.11 (d, $1 \mathrm{H}, \mathrm{CH}_{2}-\mathrm{CH}_{2}-\mathrm{NH}$, pseudo eq.), 3.59 (s, 3H, $\left.\mathrm{C} 7-\mathrm{OCH}_{3}\right), 3.80\left(\mathrm{~s}, 3 \mathrm{H}, \mathrm{C} 6-\mathrm{OCH}_{3}\right), 4.92$ (s, $\left.1 \mathrm{H}, \mathrm{CH} 1\right)$, $5.04(\mathrm{~s}, 1 \mathrm{H}, \mathrm{NH}), 6.13(\mathrm{~s}, 1 \mathrm{H}, \mathrm{CH}), 6.56(\mathrm{~s}, 1 \mathrm{H}, \mathrm{CH} 5)$, $6.94\left(\mathrm{~d}, 2 \mathrm{H}, \mathrm{CH} 2^{\prime}+6^{\prime}\right), 7.58\left(\mathrm{~d}, 2 \mathrm{H}, \mathrm{CH} 3^{\prime}+5^{\prime}\right) .{ }^{13} \mathrm{C}-\mathrm{NMR}$ $\left(\mathrm{CDCl}_{3}\right): \delta=29.1\left(1 \mathrm{C}, \mathrm{CH}_{2}-\mathrm{CH}_{2}-\mathrm{NH}\right), 41.6\left(1 \mathrm{C}, \mathrm{CH}_{2}-\mathrm{CH}_{2}-\right.$ $\mathrm{NH}), 55.7\left(1 \mathrm{C}, \mathrm{C} 6-\mathrm{OCH}_{3}\right), 55.8\left(1 \mathrm{C}, \mathrm{C} 7-\mathrm{OCH}_{3}\right), 60.8(1 \mathrm{C}$, CH1), 92.9 (1C, $\left.C 4^{\prime}-\mathrm{I}\right), 110.6$ (1C, $\left.C H 8\right), 111.4$ (1C, $\left.C H 5\right)$, 127.6 (1C, C4a), 129.0 (1C,C8a), $130.9\left(2 \mathrm{C}, C H 2^{\prime}+6^{\prime}\right)$, $137.4\left(2 \mathrm{C}, C \mathrm{H}^{\prime}+5^{\prime}\right), 144.5\left(1 \mathrm{C}, C 1^{\prime}\right), 147.1(1 \mathrm{C}, C 7-$ $\left.\mathrm{OCH}_{3}\right), 147.7\left(1 \mathrm{C}, \mathrm{C6}-\mathrm{OCH}_{3}\right) . \mathrm{MS}: \mathrm{m} / \mathrm{e} 396\left[\mathrm{MH}^{+}, 100\right]$, $397\left[\mathrm{MH}^{+}, 19\right], 398\left[\mathrm{MH}^{+}, 2\right] . \mathrm{EA}: \mathrm{C}_{17} \mathrm{H}_{18} \mathrm{INO}_{2}$ calculated: C 51.7, H 4.59, N 3.54; found: C 52.2, H 4.44, N 3.75.

\subsection{2-Acetyl-6,7-dimethoxy-1-(4'-iodophenyl)- 1,2,3,4-tetrahydro-isoquinoline (5)}

Intermediate 4 (3.4 mmol) was dissolved in acetic anhydride $(10 \mathrm{~mL})$ and heated to reflux for $90 \mathrm{~min}$. The mixture was cooled and the reaction quenched by adding water $(\sim 10 \mathrm{~mL})$. The organic layer was extracted with dichloromethane $(3 \times 10 \mathrm{~mL})$, dried over $\mathrm{Mg}_{2} \mathrm{SO}_{4}$ and the solvent was removed under reduced pressure until dryness. The oily residue was treated with ether for crystallization and washed with ether. Flash-chromatography on silica gel using $n$-hexane/acetone $(5: 2)$ gave the purified 2-acetyl-6,7-dimethoxy-1-(4'-iodo-phenyl)-1,2,3,4tetrahydroisoquinoline $(5)\left(R_{\mathrm{f}}=0.23\right)$. Yield: $1.20 \mathrm{~g}(81 \%)$. Mp: $141.3{ }^{\circ} \mathrm{C} .{ }^{1} \mathrm{H}-\mathrm{NMR}\left(\mathrm{CDCl}_{3}\right): \delta=2.10\left(\mathrm{~s}, 3 \mathrm{H}, \mathrm{CH}_{3}\right)$, 2.69 (d, $1 \mathrm{H}, \mathrm{CH}_{2}-\mathrm{CH}_{2}-\mathrm{NH}$, pseudo eq.), 2.89 (d, $1 \mathrm{H}, \mathrm{CH}_{2}-$ $\mathrm{CH}_{2}-\mathrm{NH}$, pseudo ax.), 3.29 (d, $1 \mathrm{H}, \mathrm{CH}_{2}-\mathrm{CH}_{2}-\mathrm{NH}$, pseudo ax.), 3.67 (d, $1 \mathrm{H}, \mathrm{CH}_{2}-\mathrm{CH}_{2}-\mathrm{NH}$, pseudo eq.), 3.70 (s, 3H, $\left.\mathrm{C}^{-}-\mathrm{OCH}_{3}\right), 3.83$ (s, 3H, C6-OCH $\mathrm{H}_{3}, 6.43$ (s, 1H, CH8), 6.61 (s, 1H, CH5), 6.75 (s, 1H, CH1), $7.54\left(\mathrm{~d}, 2 \mathrm{H}, \mathrm{CH}^{\prime}+5^{\prime}\right)$, $6.94\left(\mathrm{~d}, 2 \mathrm{H}, \mathrm{CH} 2^{\prime}+6^{\prime}\right) .{ }^{13} \mathrm{C}-\mathrm{NMR}\left(\mathrm{CDCl}_{3}\right): \delta=21.6(1 \mathrm{C}$, $\mathrm{CH}_{3}$ ), $28.4\left(\mathrm{C}, \mathrm{CH}_{2}-\mathrm{CH}_{2}-\mathrm{NH}\right), 40.1\left(1 \mathrm{C}, \mathrm{CH}_{2}-\mathrm{CH}_{2}-\mathrm{NH}\right)$, $53.9(1 \mathrm{C}, C \mathrm{H} 1), 55.9\left(2 \mathrm{C},-\mathrm{OCH}_{3}\right), 93.2\left(2 \mathrm{C}, C \mathrm{H}^{\prime}+\right.$ $\left.5^{\prime}\right), 110.0(2 \mathrm{C}, C \mathrm{H} 5+8), 126.2(1 \mathrm{C}, C 8 \mathrm{a}), 126.3(1 \mathrm{C}, C 4 \mathrm{a})$, $130.8\left(2 \mathrm{C}, C H 2^{\prime}+6^{\prime}\right), 137.3\left(1 \mathrm{C}, C 1^{\prime}\right), 142.2\left(1 \mathrm{C}, C 4^{\prime}-\mathrm{I}\right)$, $147.7\left(1 \mathrm{C}, \mathrm{C} 6-\mathrm{OCH}_{3}\right), 148.2\left(1 \mathrm{C}, C 7-\mathrm{OCH}_{3}\right), 168.9$ (1C, $C=\mathrm{O})$. MS: m/e $438\left[\mathrm{M}^{+}, 100\right]$. EA: $\mathrm{C}_{19} \mathrm{H}_{20} \mathrm{INO}_{3}$ calculated: C 52.2, H 4.61, N 3.20; found: C 52.7, H 4.70, N 3.41.

\subsection{2-Acetyl-6,7-dimethoxy-1-(4'-trimethylstannyl- phenyl)-1,2,3,4-tetrahydroisoquinoline (6)}

A solution of $\mathbf{5}(2 \mathrm{mmol})$, hexamethyl-distannane $(5.3 \mathrm{mmol})$ and tetrakis(triphenylphos-phine) palladium $(30 \mu \mathrm{mol})$ in $50 \mathrm{~mL}$ toluene was heated until reflux for $3 \mathrm{~h}$. The solvent was removed under reduced pressure and the crude product was purified by column chromatography using silica gel and $n$-hexane/ethyl acetate $(1: 10)$ to give $6\left(R_{\mathrm{f}}=0.69\right)$. Yield: $0.65 \mathrm{~g}(68 \%)$. Mp: $117.2{ }^{\circ} \mathrm{C} .{ }^{1} \mathrm{H}-\mathrm{NMR}$ $\left(\mathrm{CDCl}_{3}\right): \delta=0.21\left(\mathrm{~s}, 9 \mathrm{H}, \mathrm{Sn}\left(\mathrm{CH}_{3}\right)_{3}\right), 2.11\left(\mathrm{~s}, 3 \mathrm{H},-\mathrm{CH}_{3}\right)$, 2.70 (d, $1 \mathrm{H}, \mathrm{CH}_{2}-\mathrm{CH}_{2}-\mathrm{NH}$, pseudo eq.), 2.89 (d, $1 \mathrm{H}, \mathrm{CH}_{2}-$ $\mathrm{CH}_{2}-\mathrm{NH}$, pseudo ax.), 3.34 (d, $1 \mathrm{H}, \mathrm{CH}_{2}-\mathrm{CH}_{2}-\mathrm{NH}$, pseudo ax.), 3.64 (d, $1 \mathrm{H}, \mathrm{CH}_{2}-\mathrm{CH}_{2}-\mathrm{NH}$, pseudo eq.), 3.71 (s, 3H, 
C7-OCH $\left.H_{3}\right), 3.84$ (s, 3H, C6-OCH $\left.H_{3}\right), 6.48$ (s, 1H, CH8), 6.61 (s, 1H, CH5), $6.82(\mathrm{~s}, 1 \mathrm{H}, \mathrm{CH} 1), 6.95\left(\mathrm{~d}, 2 \mathrm{H}, \mathrm{CH}^{\prime}+\right.$ $\left.5^{\prime}\right), 7.14\left(\mathrm{~d}, 2 \mathrm{H}, \mathrm{CH} 2^{\prime}+6^{\prime}\right) .{ }^{13} \mathrm{C}-\mathrm{NMR}\left(\mathrm{CDCl}_{3}\right): \delta=-9.6$ $\left(3 \mathrm{C}, \mathrm{Sn}\left(\mathrm{CH}_{3}\right)_{3}\right), 21.6\left(1 \mathrm{C}, \mathrm{CH}_{3}\right), 28.5\left(1 \mathrm{C}, \mathrm{CH}_{2}-\mathrm{CH}_{2}-\mathrm{NH}\right)$, $40.1\left(1 \mathrm{C}, \mathrm{CH}_{2}-\mathrm{CH}_{2}-\mathrm{NH}\right), 54.3$ (1C, $\left.\mathrm{CH} 1\right), 55.8$ (1C, C6$\left.\mathrm{OCH}_{3}\right), 55.9\left(1 \mathrm{C}, \mathrm{C} 7-\mathrm{OCH}_{3}\right), 111.0(1 \mathrm{C}, \mathrm{CH} 5), 111.2(1 \mathrm{C}$, CH8), 126.3 (1C, C4a), 126.9 (1C, C8a), 128.4 (2C, CH3'+ $\left.5^{\prime}\right), 135.7\left(2 \mathrm{C}, C H 2^{\prime}+6^{\prime}\right), 141.3\left(1 \mathrm{C}, C 4^{\prime}-\mathrm{Sn}\right), 142.4(1 \mathrm{C}$, $\left.C 1^{\prime}\right), 147.6\left(1 \mathrm{C}, C 7-\mathrm{OCH}_{3}\right), 148.0\left(1 \mathrm{C}, C 6-\mathrm{OCH}_{3}\right), 168.8$ (1C, C=O). MS: m/e 476 [M+ , 100], 474 [76], 472 [39], 480 [16]. EA: $\mathrm{C}_{22} \mathrm{H}_{29} \mathrm{NO}_{3} \mathrm{Sn}$ calculated: C 55.7, $\mathrm{H} 6.16, \mathrm{~N} 2.95$; found: C 55.4, H 6.19, N 3.09 .

\subsection{N-acetyl-1-(4' - $\left[{ }^{131} I\right]$ iodo-phenyl $)$-aryl- 6,7-dimethoxy-1,2,3,4-tetrahydroisoquinoline $\left(\left[{ }^{131} \mathrm{I}\right] 5\right)$}

To $50 \mu \mathrm{l}$ of a solution of 6 in ethanol $(c=0.2 \mu \mathrm{mol} / \mathrm{mL})$ and $5 \mu \mathrm{L}$ of an aqueous chloramine-T solution $(1 \mathrm{M}), 5 \mu \mathrm{L}(\sim$ $7.5 \mathrm{MBq})$ of sodium $\left[{ }^{131} \mathrm{I}\right]$ iodine solution $(\sim 1.48 \mathrm{GBq} / \mathrm{mL})$ was added. After addition of $5 \mu \mathrm{L}$ hydrochloric acid solution $(1 \mathrm{M})$, the reaction vial was shaken for $2 \mathrm{~min}$ at room temperature. To stop the reaction, about $100 \mu \mathrm{L}$ of the HPLC eluent (methanol/water, $70: 30$ ) was added. The product $\left[{ }^{131} \mathrm{I}\right] 5$ was analysed and separated by radio-HPLC (flow: $0.8 \mathrm{~mL} / \mathrm{min})$.

\subsection{In vitro autoradiography}

For autoradiography, frozen brains of Wistar rats were cut horizontally at $-18{ }^{\circ} \mathrm{C}$ into $20 \mu \mathrm{m}$ thick sections (Leica AG Microsystems, Germany), mounted onto gelatine-coated object glasses (LO-Laboroptik $\mathrm{GmbH}$ ) and stored at $-80^{\circ} \mathrm{C}$ until use. For the assay, the brain sections were thawed and dried at room temperature. After preincubation for $15 \mathrm{~min}$ at $4{ }^{\circ} \mathrm{C}$ in a $50 \mathrm{mM}$ Tris- $\mathrm{HCl}$ solution containing $0.5 \mathrm{mM}$ $\mathrm{CaCl}_{2}$, the cryosections were analoguously incubated $(6 \mathrm{sec}-$ tions per $15 \mathrm{~mL}$ ) with $50 \mathrm{mM} \mathrm{KSCN}$ and $0.5 \mathrm{nM}$ or $7.5 \mathrm{nM}$ of $\left[{ }^{131} \mathrm{I}\right] 5\left(A_{\mathrm{S}}=0.79 \mathrm{GBq} / \mu \mathrm{mol}\right)$ in the buffer for $45 \mathrm{~min}$ at $4{ }^{\circ} \mathrm{C}$. Adjacent sections were incubated in the presence of $15 \mu \mathrm{M}$ unlabeled 5 or the AMPA antagonist CNQX. After treatment the sections were washed twice for $15 \mathrm{~s}$ in buffer without $\mathrm{KSCN}$ at $4{ }^{\circ} \mathrm{C}$, dipped in deionised water, dried and exposed for $45 \mathrm{~min}$ to a phosphor imaging plate (Fuji).

\subsection{Ex vivo autoradiography}

To investigate if $\left[{ }^{131} \mathrm{I}\right] 5$ passes the blood-brain barrier, female NMRI mice weighing $25 \pm 2 \mathrm{~g}$ received about $150 \mathrm{kBq}$ $\left[{ }^{131} \mathrm{I}\right] 5\left(0.22 \mathrm{nmol}, A_{\mathrm{S}}=681 \mathrm{GBq} / \mathrm{mmol}\right)$ by tail vein injection. The animals were sacrificed $10 \mathrm{~min}$ and $60 \mathrm{~min}$ after radiotracer injection, the brains removed, weighed and the radioactivity measured with a $\gamma$-counter. For ex vivo autoradiography the brains were frozen, cut into $40 \mu \mathrm{m}$ thick horizontal slices and exposed to a phosphor imaging plate (Fuji).

\subsection{Autoradiography data acquisition}

The phosphor imaging plates were scanned with a laser phosphor imager (BAS 5000, Fuji) utilizing software from the vendor (Version 3.14, Raytest, Germany). Data from regions of interest were obtained by the image analyzer pro- gram AIDA (Version 3.52, Raytest Germany) and transferred to an Excel program.

\section{Results and discussion}

\subsection{Chemistry}

The syntheses of the non-radioactive reference compound $N$-acetyl-1-(4' -iodophenyl)-6,7-dimethoxy-1,2,3,4-tetrahydroiso-quinoline (5) and of the precursor for radiolabeling, $\mathrm{N}$-acetyl-1-(4'-trimethylstannylphenyl)-6,7-dimethoxy1,2,3,4-tetrahydroiso-quinoline (6), were modified from a described procedure (cf. Fig. 2) [6]. The condensation of 2-(3',4'-dimethoxyphenyl)-ethylamine (1) with 4iodobenzaldehyde (2) gave the desired 4-iodo-benzyl[2(3',4'-dimethoxy-phenyl)-ethyl]imine (3). This imine was heated to reflux in trifluoroacetic acid for the final ring closure according to the Pictet-Spengler approach. The intermediate 6,7-dimethoxy-1-(4'-iodophenyl)-1,2,3,4-tetrahydroisoquinoline (4) was $N$-acetylated by refluxing in acetic anhydride to give the reference compound $\mathbf{5}$ with $27 \%$ overall yield after three steps. For preparation of the labeling precursor, compound $\mathbf{5}$ was stannylated by hexamethyldistannane using the catalyst tetrakis-(triphenylphosphine) palladium. The product $\mathbf{6}$ was obtained after column chromatographic purification in $68 \%$ yield.

\subsection{Radiochemistry}

Very efficient radioiodination was achieved by the electrophilic destannylation of $\mathbf{6}$ with sodium $\left[{ }^{131} \mathrm{I}\right]$ iodide in the presence of chloramine-T (CAT) as oxidant (Fig. 2). After 2 min reaction time at room temperature, an excellent radiochemical yield (rcy) of $97 \%$ of $\left[{ }^{131} \mathrm{I}\right] 5$ was obtained (Fig. 3). The product mixture was purified by radio-HPLC and employed in pharmacological studies for preliminary evaluation.

The quality control chromatograms showed always excellent radiochemical purity of $\left[{ }^{131} \mathrm{I}\right] 5$ of $\geq 99 \%$. With ${ }^{131} \mathrm{I}$ starting activities of $\sim 7.5 \mathrm{MBq}$ an average specific activity of $\left[{ }^{131} \mathrm{I}\right] 5$ of $681 \mathrm{GBq} / \mathrm{mmol}$ was achieved.

\subsection{Pharmacological evaluation}

For preliminary pharmacological evaluation of $\left[{ }^{131} \mathrm{I}\right] 5$, two studies were performed. In a first in vitro autoradiography study, brain slices of Wistar rats were incubated with $\left[{ }^{131} \mathrm{I}\right] 5$ in absence and presence of blocking ligands. An additional ex vivo study was performed in order to investigate the ability of $\left[{ }^{131} \mathrm{I}\right] 5$ for passing the blood-brain barrier (BBB). For this test, $150 \mathrm{kBq}\left[{ }^{131} \mathrm{I}\right] 5\left(A_{\mathrm{S}}=681 \mathrm{GBq} / \mathrm{mmol}, 0.22 \mathrm{nmol}\right)$ were injected into a tail vein of female NMRI mice. After 10 or $60 \mathrm{~min}$, brains were removed, blotted dry, and measured in a $\gamma$-counter for radioactivity. In addition, the dissected brains were cut into horizontal slices and measured autoradiographically.

The autoradiograms of the in vitro incubated brain slices revealed an uniform distribution of $\left[{ }^{131} \mathrm{I}\right] 5$ binding without any cognizable brain structure. In the cerebral cortex, not more than $20 \%$ of specific binding was measured using $15 \mu \mathrm{M}$ unlabeled 5 to determine the nonspecific binding. 
<smiles>COc1ccc(CCN)cc1OC</smiles><smiles>O=Cc1ccc(I)cc1</smiles>

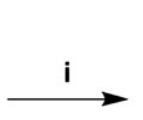<smiles>COc1ccc(CC/N=C\c2ccc(I)cc2)cc1OC</smiles><smiles>C#CC</smiles><smiles>COc1cc2c(cc1OC)C(c1ccc(I)cc1)NCC2</smiles><smiles>CC#CCCCC(=O)N1CCc2cc(OC)c(OC)cc2C1c1ccc(I)cc1</smiles>
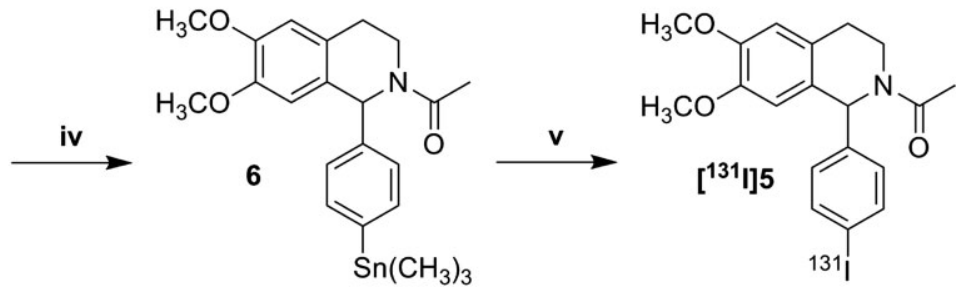

Fig. 2. Synthesis of the reference compound $\mathbf{5}$, the radiolabeling precursor $\mathbf{6}$ and the new radioligand $\left[{ }^{131} \mathrm{I}\right] 5$. Reaction conditions: (i) anhydrous toluene, reflux, $3 \mathrm{~h}$; (ii) trifluoroacetic acid, reflux, $90 \mathrm{~min}$; (iii) acetic anhydride, reflux, $90 \mathrm{~min}$; (iv) hexamethyldistannane, tetrakis(triphenylphosphine) palladium, toluene, reflux, $3 \mathrm{~h}$; (v) sodium $\left[{ }^{131} \mathrm{I}\right]$ iodide solution, chloramine-T, hydrochloric acid, room temperature, 2 min.

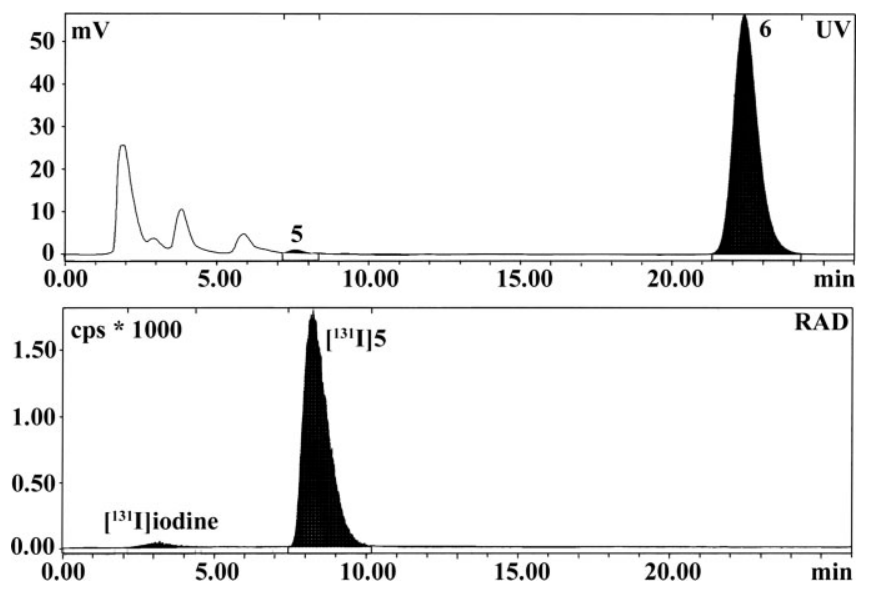

Fig. 3. Chromatogram of the radio-HPLC purification of $\left.{ }^{131} \mathrm{I}\right] 5$. Top channel presents the UV trace, the lower channel shows the radioactivity signal.

Blocking with the AMPA antagonist CNQX (6-cyano-7nitroquinoxaline-2,3-dione) resulted in only about $7 \%$ specific binding at $0.5 \mathrm{nM}\left[{ }^{131} \mathrm{I}\right] 5$ and about $25 \%$ specific binding at $7.5 \mathrm{nM}\left[{ }^{131} \mathrm{I}\right] 5\left(A_{\mathrm{S}}=0.79 \mathrm{GBq} / \mu \mathrm{mol}\right)$. Measurements of the radioligand concentration in incubation buffer solutions (supernatant) showed a corresponding strong depletion of the radioligand of $21 \%$ at $0.5 \mathrm{nM}$ and of $13 \%$ at $7.5 \mathrm{nM}$ after in vitro brain tissue incubation.

The ex vivo tests revealed that $\left[{ }^{131} \mathrm{I}\right] 5$ penetrated the blood-brain barrier, accumulating in the whole brain to an extent of $2.1 \% \mathrm{ID} / \mathrm{g} 10 \mathrm{~min}$ after injection and decreased to only $0.2 \% \mathrm{ID} / \mathrm{g}$ after $60 \mathrm{~min}$. Again the ex vivo autoradiography exhibited a uniformly distributed radioactivity, both, $10 \mathrm{~min}$ and $60 \mathrm{~min}$ post injection.

Specific noncompetitive AMPA receptor antagonists have been described as potent anticonvusant agents [810] including $N$-acetyl-1-aryl-6,7-dimethoxy-1,2,3,4-tetrahydroisoquinoline with different substituents in the 4'position of the aryl group [6]. Since AMPA receptors are involved in neurodegenerative processes occurring in diseases like epilepsy, ischemia and Parkinson's disease, an appropriate radioligand to visualize these receptors with molecular imaging techniques is of particular interest for diagnosis and decision of drug treatment.

Recently, a ${ }^{11} \mathrm{C}$-labeled and three ${ }^{18} \mathrm{~F}$-labeled derivatives of $N$-acetyl-1-aryl-6,7-dimethoxy-1,2,3,4-tetrahydroisoquinoline have been synthesized [11]. The $N$-acetyl-1(4'chlorophenyl)-6,7-dimethoxy-1,2,3,4-tetrahydroisoquinoline has already been labeled with tritium for in vitro characterization and showed in rat cortical membranes a possibly saturable binding with a $K_{\mathrm{d}}$ of about $15 \mathrm{nM}$ [12]. In the present in vitro autoradiography studies with $\left[{ }^{131} \mathrm{I}\right] 5$, not even a specific binding of $50 \%$ could be achieved. As noncompetitive antagonists $\mathbf{5}$ and its derivatives bind irreversible to the AMPA receptor and change the receptor in a way which precludes agonists' binding. An advantage might be that the endogenous neurotransmitter would not influence this binding by competition [12]. However, the nature of this ligand binding to the receptor is still unknown, and thus it is not sure if the binding follows the simple equations of the law of mass action. Additionally, a high depletion of the $\left[{ }^{131} \mathrm{I}\right] 5$ concentration in the incubation buffer solutions was observed in the in vitro studies giving a hint on a massive absorption of different binding characteristics. The in vivo uptake of $\left[{ }^{131} \mathrm{I}\right] 5$ in mice brain was comparable with the ${ }^{11} \mathrm{C}$-labeled $\mathrm{N}$-acetyl-1-(4' chlorophenyl)-6,7-di[6$\left.{ }^{11} \mathrm{C}\right]$ methoxy-1,2,3,4-tetrahydroisoquinoline uptake in rats concerning the moderate high accumulation after $10 \mathrm{~min}$ together with the fast clearance as well as the uniform distribution in the brain [11].

\section{Conclusions}

In conclusion, a new iodinated derivative, $N$-acetyl-1-(4'iodophenyl)-6,7-dimethoxy-1,2,3,4-tetrahydroisoquinoline, of the isoquinoline-based high affinity AMPA receptor ligands was successfully synthesized. The corresponding ${ }^{131} \mathrm{I}-$ labeled radioligand was obtained via a highly efficient electrophilic radioiodo-destannylation reaction giving $\geq 97 \%$ 
radiochemical yield within $2 \mathrm{~min}$ at room temperature. The preliminary pharmacological evaluation studies of $\left[{ }^{131} \mathrm{I}\right] 5$ show evidence for a very high nonspecific binding of the new ligand. Although the brain uptake of $\left[{ }^{131} \mathrm{I}\right] 5$ is excellent, the fast clearance appears unfavorable for a neuroimaging ligand. Further, the uniform distribution, both in vitro and in vivo, reveals $\left[{ }^{131} \mathrm{I}\right] 5$ to be a rather unsuitable radioligand for imaging of AMPA receptors.

Acknowledgment. The authors thank Dr. M. Holschbach, and Dr. D. Bier, both at FZ-Juelich, for recording NMR and MS spectra and elemental analysis as well as for their advice with radioiodination reactions.

\section{References}

1. Traynelis, S. F., Wollmuth, L. P., McBain, C. J., Menniti, F. S., Vance, K. M., Ogden, K. K., Hansen, K. B., Yuan, H. J., Myers, S. J., Dingledine, R.: Glutamate receptor ion channels: structure, regulation, and function. Pharmacol. Rev. 62, 405-496 (2010).

2. Mellor, I. R.: The AMPA receptor as a therapeutic target: current perspectives and emerging possibilities. Future Med. Chem. 2, 877-891 (2010).

3. Coenen, H. H., Elsinga, P. H., Iwata, R., Kilbourn, M. R., Pillai, M. R. A., Rajan, M. G. R., Wagner Jr., H. N., Zaknun, J. J. Fluorine-18 radiopharmaceuticals beyond $\left[{ }^{18} \mathrm{~F}\right] \mathrm{FDG}$ for use in oncology and neurosciences. Nucl. Med. Biol. 37, 727-740 (2010).

4. Nikolaus, S., Antke, C., Mueller, H. W.: In vivo imaging of synaptic function in the central nervous system. I. Movement disorders and dementia. Behav. Brain Res. 204, 1-31 (2009).
5. Coenen, H. H., Mertens, J., Mazieère, B.: Radioiodination Reactions for Radiopharmaceuticals. Springer, Dordrecht (2006).

6. Gitto, R., Barreca, M. L., De Luca, L., De Sarro, G., Ferreri, G., Quartarone, S., Russo, E., Constanti, G., Chimirri, A.: Discovery of a novel and highly potent noncompetitive AMPA receptor antagonist. J. Med. Chem. 46, 197-200 (2003).

7. Ferreri, G., Chimirri, A., Russo, E., Gitto, R., Gareri, P., De Sarro, A., De Sarro, G.: Comparative anticonvulsant activity of $\mathrm{N}$-acetyl-1-aryl-6,7-dimethoxy-1,2,3,4-tetrahydroisoquino-line derivatives in rodents. Pharmacol. Biochem. Behav. 77, 85-94 (2004).

8. De Sarro, G., Chimirri, A., De Sarro, A., Gitto, R., Grasso, S., Giusti, P., Chapman, A. G.: GYKI 52466 and related 2,3-benzodiazepines as anticonvulsant agents in DBA/2 mice. Eur. J. Pharmacol. 294, 411-422 (1995).

9. Zappala, M., Gitto, R., Bevacqua, F., Quaratarone, S., Chimirri, A., Rizzo, M., De Sarro, G., De Sarro, A.: Synthesis and evaluation of pharmacological and pharmacokinetic properties of $11 \mathrm{H}$ $[1,2,4]$ Triazolo[4,5-c][2,3]benzodiazepin-3(2H)-ones. J. Med. Chem. 43, 4834 (2000).

10. Andrási, F.: Talampanel. Antiepileptic, neuroprotectant, skeletal muscle relaxant. Drugs Future 26, 754-756 (2001).

11. Gao, M., Kong, D., Clearfield, A., Zheng, Q. H.: Synthesis of carbon-11 and fluorine-18 labeled $N$-acetyl-1-aryl-6,7-di-methoxy-1,2,3,4-tetrahydroisoquinoline derivatives as new potential PET AMPA receptor ligands. Bioorg. Med. Chem. Lett. 16, 2229-2233 (2006).

12. Årstad, E., Gitto, R., Chimirri, A., Caruso, R., Constanti, A., Turton, D., Hume, S. P., Ahmad, R., Pilowsky, L. S., Luthra, S. K.: Closing in on the AMPA receptor: Synthesis and evaluation of 2-acetyl-1-(40-chlorophenyl)-6-methoxy-7-[ $\left.{ }^{11} \mathrm{C}\right]$ methoxy-1,2,3,4tetrahydroisoquinoline as a potential PET tracer. Bioorg. Med. Chem. 14, 4712-4717 (2006). 